\title{
(RE)DEFINING PLACES FOR COMMUNITY IN SYKHIV HOUSING ESTATE
}

\begin{abstract}
Lviv (Ukraine) is an Eastern European city with a history dating back to the $13^{\text {th }}$ century. It could be imagined as a palimpsest-like place of different architectural, social, and cultural heritages. However, the majority of current Lviv's population lives within an urban environment designed and constructed during the second half of $20^{\text {th }}$ century. Based on sociological data (in-depth semi-structured interviews, survey, and unobtrusive observation) article reviews the specifics of places for community in the largest mass housing estate - Sykhiv. Author shows what areas are perceived by inhabitants as the locations for social life and what types of social cohesion could contribute to the urban transformations.
\end{abstract}

Keywords: Community, social bonds, (post)socialist city, mass housing estate, spatial transformations, Sykhiv, Lviv.

\section{Introduction}

According to Ivan Szelenyi, "socialist city," compared to "capitalist" one, has less diversity, less marginality, and is less space saving (Szelenyi 1996: 300). Therefore, it is often characterized with recurring, predictable, standardized environments and huge open areas. After 1989/1991, urban spaces of former "socialist cities" are constantly redefined ${ }^{1}$. Areas for common usage, with no specific content, started to be filled with various functional elements and symbolic meanings. This process became extremely vibrant within centrally designed environment of modernist housing estates. During the period of 1990s, with tough economic conditions and establishment of a new system of power relations, there were hardly any resources to take care of common areas. These spaces were either perceived as owned by nobody, and consequently privatized, or were generally abandoned. Some of the former open spaces started to be used as religious sites or big shopping malls. As

\footnotetext{
${ }^{1}$ T. Darieva, W. Kaschuba, M. Krebs (eds.) (2011); A. Kleims, M. Dmitrieva (eds.), (2010).
} 
a result, social life of modernist housing estates was arranged mainly between consumption, entertainment, religion, and transition from home to work and back.

Within the frame of the project „Planned Urbanity in Socialism and Beyond” conducted at the Center for Urban History of East Central Europe I would like to discuss the process of (re)defining of the places for community in modernist environment based on experience of local inhabitants. As a primarily case for this study I would use Sykhiv, the biggest (located on the territory of 390 hectares) housing estate in Lviv, western Ukraine. As for 2001, 146847 residents lived there (Cherkes 2013: 68). This area was centrally designed under the concept of micro-district and was constructed mainly during 1980s. The residential 9-storey and 15-storey buildings were made of prefabricated panel blocks and became the accommodation for workers of the south-eastern industrial hub of the city. Since construction open spaces of Sykhiv as well as areas for common usage were constantly reshaped and reappropriated by various actors. With this research I intended to see the role of local community in this process.

\section{Community in mass housing: places to be}

Annemarie Sammartino pointed out that one of the differences between late modernism and modernism of the first two post-war decades was the target: the first one aimed to develop a new kind of community with the help of urban planning and architectural means (Sammartino 2016: 497). The city under socialism, as Astrid Ihle puts it, ,was conceived as a public space designed to support the process of social integration and the formation of a new socialist citizen" (Ihle 2002: 90). Thus, it had to facilitate a certain type of social bonds among people: new ways of spatial organization and material environments had to produce new social relations, personal identities, and systems of values. The influence of physical space on social structure and individual behavior was implicitly assumed as linear. According to David Crowley and Susan Reid, "the architectural form of the city and planning of urban space were vested with a social-transformative role in the lives of its residents" (Crowley, Reid 2002: 11). However, the relationship between space, materiality, social structures, and human agency is rather mutual and might be visualized as a network with various types of connections that influence each other in different ways.

Kenny Cupers reviews the interrelations between sociological theorizing of community and urban planning in Western Europe in 1940s and 1950s. He stated that the dominance of the ecological concept of habitat led to "the assumption that spatial proximity equaled social bonding" (Cupers 2016: 1012). Strongly influential during the $20^{\text {th }}$ century, this determinist approach was gradually replaced by the „reciprocity of interaction” (Cupers 2016: 1023) as a key precondition for the existence of community. According to this shift, the links and social cohesion 
between different actors become crucial for the development of community. They might be established within the space, which could be defined with four qualities: 1) accessibility, 2) possibility to be engaged in activities around, 3) comfort as well as a good public image, and 4) sociability, therefore the ability of people to meet each other and interact there ${ }^{2}$. Basically these are the qualities of places of encounters, informational and emotional interactions, to which I would refer as "places for community". With this name, instead of "public space," I am emphasizing both social (in terms of links) and local (in terms of specific space) aspects of such areas.

The recurring type of Soviet city landscape during the period of 1950s-1990s has transformed, according to Philipp Meuser, from "the neoclassical superblock to the socialist micro-district" (Meuser 2015: 145). One of the key ideas behind the latter was the System of Stepped Services (Zadorin 2009: 26). It meant spatial proximity of services based on the frequency of their usage. Sykhiv area was divided into thirteen micro-districts (M11-M23) with planned community centers in each. According to Bohdan Cherkes, such centers had to fulfill six functions: trade, health care, public services, administration, education, culture and sport, and hotel accommodation (Cherkes 2013:69). Despite the requirement to construct community service buildings, they were not completely accomplished: priority was given to housing facilities. As a result, this modernist mass housing estate might lack places, where locals can meet and spend time together. This is an assumption, which has to be checked.

\section{Methods and questions}

After 1989-1991, modernist mass housing entered the process of still-lasting reinterpretation according to new social conditions, expectations, and visions of the future. What spaces are perceived by local people as the places for community? Are they those envisioned from the very beginning at the level of planning, or constructed after 1991, or constantly reinvented and recreated? How do local residents define the qualities of such spaces? What activities support their existence? I assume that urban space is constantly recreated and redefined through the network of spaces, social structures, everyday practices, objects and symbols with various types of connections that influence each other in different ways. My main focus is made on one of the nodes of this network: people and their activities. Therefore, I used various sociological data: in-depth interviews with inhabitants (total of 11 semi-structured interviews, collected in 2015 with purposive quota sample), unobtrusive observations during Summer 2015 and Summer 2017, purposive sample with quotas of gender and

${ }^{2}$ Project for Public Spaces (2009), http://www.pps.org/reference/grplacefeat/ (accessed on: 17.07.2017). 
age and results of sociological unstructured survey „Problems and Needs of the Inhabitants of Sykhiv District," which was conducted during July 2017 by the City Institute in cooperation with Civic Network OPORA ${ }^{3}$. This survey used a multi-stage proportional stratification sample with quota selection at the last stage. A total of 600 persons were interviewed with the "face-to-face" method. Based on these materials, I would like to delineate the process of reassembling of both material environment and social life in modernist mass housing.

\section{Sykhiv case study}

Philipp Meuser points out that economic practicability in terms of resources "dictated form, function and structure" (Meuser 2015: 156). As a result, community centers either were not fully constructed or their functions were redefined under new „capitalist" conditions. For example, "Zubra-Center" (named after a local river, popularly referred to as "Santa Barbara" because of visual similarity of its arches with the opening scene of American television soap opera, community center of M22) gradually transformed into a trade center. "Iskra" ("Spark", named after Lviv Electric Lamp Factory, community center of M11) had a similar fate. Together with local public centers in every micro-district, Sykhiv had a large-scale center at the intersection of the major transport and pedestrian flows, Chervona Kalyna avenue and Sykhivska street. This center on the crossroads with exaggerated space became fragmented during 1990s as well. Partly, it was used to construct a Nativity of Blessed Virgin Mary church, partly it was filled with trade, sport, and entertainment facilities, and partly it became a transit area and a green zone for walking or leisure.

The sociological survey „Problems and Needs of the Inhabitants of Sykhiv District" could illustrate the ways how local inhabitants relate to their neighborhood. There was a question about spaces, which I define as "place for community", and people named courtyards between large-block apartment buildings, green zones, walking areas, cultural infrastructure, such as libraries or cinema (see Table 1). Religious sites also are perceived as the places of communication and interaction, as well as cafés or shops, even when they have limited access and restricted range of activities. Out of those, who agreed on the presence of places for community in their district, $60,6 \%$ respondents spend their free time there. Still, there is a big number of people, who feel lack of possibilities to interact with others.

\footnotetext{
${ }^{3}$ Survey „Problems and Needs of the Inhabitants of Sykhiv District” was conducted within the framework of the project ,Support to the Reform of Decentralization in Ukraine" funded by the British Embassy in Ukraine.

${ }^{4}$ The question was "Are there any places in the district where residents can chat, discuss problems, or spend time together?".
} 


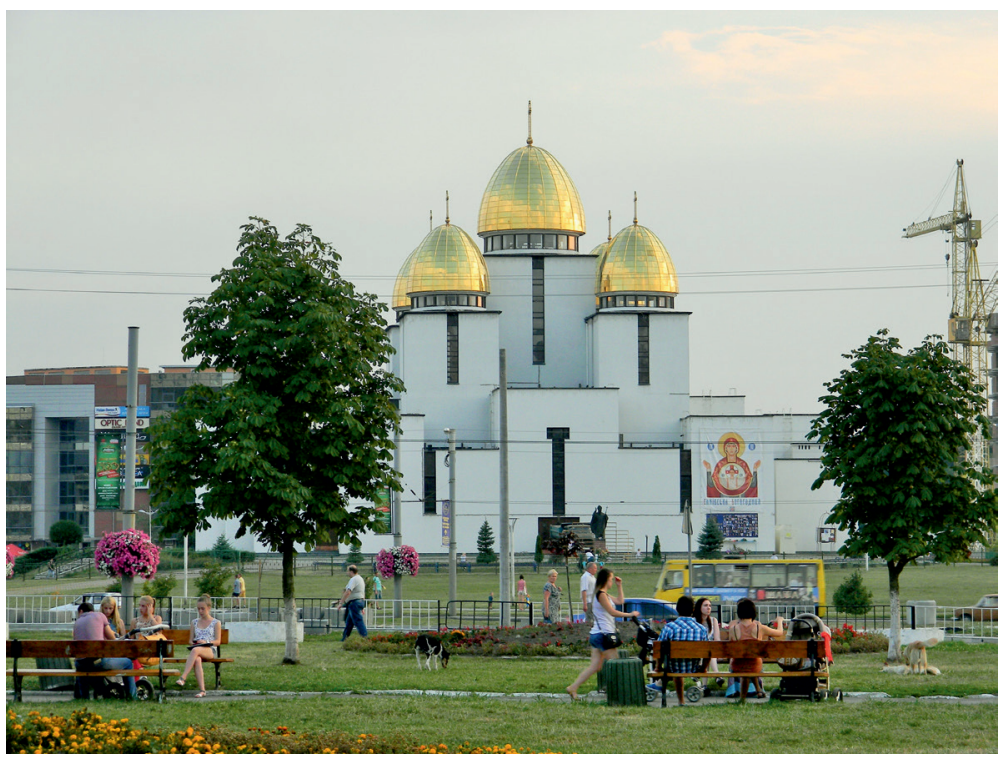

Figure 1. Central square of Sykhiv housing estate with "Intercity" trade center and Nativity of Blessed Virgin Mary Church on the background

$$
\text { photo: N. Otrishchenko (2015) }
$$

Table 1. Places in the district where residents can spend time together $(\%)^{*}$

\begin{tabular}{lc}
\hline Green zones & 19,6 \\
\hline Areas near buildings (yards, benches, gazebos, playgrounds) & 19,6 \\
\hline Cinema & 17,9 \\
\hline Religious sites & 16,1 \\
\hline Playgrounds, school & 14,3 \\
\hline Public catering (cafés, restaurants), shops & 12,5 \\
\hline \% of those who believe there are areas where residents can spend time &
\end{tabular}

Source: Lviv City Institute survey (2017)

More detailed picture could be developed with the help of 11 in-depth interviews collected in 2015 by my colleague Natalia Mysak and me $e^{5}$. The inter-

\footnotetext{
${ }^{5}$ Interviews were collected for the „Imagined and Experienced: Planned Districts in Late Socialism and Beyond" project, conducted at the Center for Urban History. See details here: http://www.lvivcenter.org/en/ researchprojects/imagined-and-experienced/ (accessed on: 13.12.2017). Quotes are translated from Ukrainian. According to the confidentiality policy, only information about gender and age of interviewees will be provided.
} 
section of Chervona Kalyna avenue and Sykhivska street is perceived as the center of community life of the district: "There is a Nativity of Blessed Mother Mary church with a park and a cinema, perfectly fitted into the public space, in the core of the center, where all young people are going out in the evenings... and further there are intimate inner courtyards, where most of my friends grew up"6; "I think that the center of the city is a square in front of the cinema, near the church. It is the main part of the city of Sykhiv"7. In the second quote the interviewee is referring to Sykhiv as a "city," which is quite a common tendency - during decades it has been infrastructurally and symbolically separated from the rest of Lviv, and, as the other interviewee mentioned, „I could often hear from people 'I am going out to the city'. They do not associate Sykhiv with the city" ${ }^{\prime \prime}$. He also recalled courtyards as an important place of socialization. Similar attitude was expressed by another young man who described the role of space in the construction of friendship networks: "During school years, some were rallying around the school... Personally, I was not attached to the courtyards, but I assume that the majority of people were [attached]. The [children from] porches or courtyards were friends and so on. I, we were friends based on our interests, not (laughs) geographic affiliation"".

Sykhiv playgrounds could be an example of places for local community as well, nevertheless, they are designed mainly for the activities of one target group - children (with the support or supervision of their parents or grandparents): "Recently, I really enjoyed that there has been an increase in the number of areas for children, the playgrounds. And I would like to see big flower beds next to each house. I love flowers, I love when there is a lot of greenery; the more greenery, I think, the better" 10 ; "All playgrounds are concentrated... were built during the Soviet Union near schools. There are a few playgrounds near the 'Intercity' [trade center] and small sportsgrounds, too, but it is not enough" ". These two interviewees have different attitudes on the number of playgrounds. The possible reason for this might be the difference in their definitions of a "playground", because it could be perceived either as exclusive outdoor area provided only for children to play on or as inclusive arena for activities like sports or recreation that could also be used by adults. At the same time, local children perceived the whole area as a huge space, which they can appropriate and use for various activities: "I do not remember that we spent time at the territories allocated for children, where there was one swing, one slide and so on. All micro-district was a playground [for us]"12.

\footnotetext{
${ }^{6}$ Male, 26, 14 July 2015.

${ }^{7}$ Female, 43, 12 August 2015.

${ }^{8}$ Male, 26, 14 July 2015.

${ }_{9}^{9}$ Male, 30, 6 August 2015.

${ }^{10}$ Female, 43, 12 August 2015.

${ }^{11}$ Male, 31, 7 August 2015.

${ }^{12}$ Male, 22, 16 July 2015.
} 
Greenery is one of the district's benefits, which is among the most frequently mentioned in the interviews: "I always liked the amount of space. A lot of space. It was a lot of greenery, in my mind there always has been the walk as in this huge park, especially I remember [it] during summers. So, this was my first encounter with Sykhiv and with Lviv"13; "After two years, when I became a mother, I realized that Sykhiv is a perfect place not only because of the market and huge bazaar nearby... such a quiet green area extremely pleased me as a mother"14. Green zones played an important role in a "socialist city," as environmental discourse largely contributed to modernist mass housing programs. However, those spaces also transformed because of activities of local community: "Others are making kind of green zones, [with] flowers, lawns. We did not have anything like that. Just a tree and grass. Once there was an attempt to plant something, but it was immediately trampled, destroyed"15. This interviewee continues on the issue of privatization of former spaces for common usage - staircases, garbage piping etc. - and their conversion into pantries and storage rooms. He calls it "a struggle for space" ${ }^{16}$. One of the main changes in spatial development that occurred after the breakdown of the Soviet Union was the increase of the number of actors on various levels, and the blurring of the borders of their responsibility for common spaces, therefore, a number of common places became private property.

Interaction between these actors, coordination of their efforts, and active personal involvement is one of the key mechanisms of development of the places for community. It requires certain investment of resources and is mainly based on the development of local landscape, on making it more convenient: "Well, these initiatives, the greenery around the house was created by us... The playground near our house, we put to order by ourselves, in fact, from the very beginning... It was my initiative as the head of a housing cooperative did not allow to plant potatoes. We decided to make a lawn and we still have this lawn"17; "Maybe [we need] more recreational places, benches, so people, mothers with baby strollers could sit down somewhere... And, of course, the Sykhiv forest, we must improve it - to put in trash bins, benches with tables - to make a parkland" ${ }^{\prime 18}$. Contemporary Sykhiv (particularly - Santa Barbara) is also an area where one of the first and most interesting examples of Lviv's urban participatory planning is developing now - "the Square of Dignity". Architects and local activists consolidated their efforts to stop the construction of a trade center that violated building norms ${ }^{19}$.

${ }^{13}$ Ibidem.

${ }^{14}$ Female, 33, 4 August 2015.

${ }^{15}$ Male, 30, 6 August 2015.

${ }^{16}$ Ibidem.

${ }^{17}$ Male, 64, 21 August 2015.

${ }^{18}$ Female, 25, 14 July 2015.

${ }^{19}$ More information about this project is available on its facebook-page: https://www. facebook.com/skverinsykhiv (accessed on: 13.12.2017). 
Further, protesters initiated to conduct a research, to involve local residents into decision-making process, to join with city authorities and finally to make this space accessible and attractive for local community. As one of the activists describes her motivation: "And why am I involved in the creation of Sykhiv now? It is the place where I live, I want this place to be better, I believe that people deserve it" ${ }^{20}$.

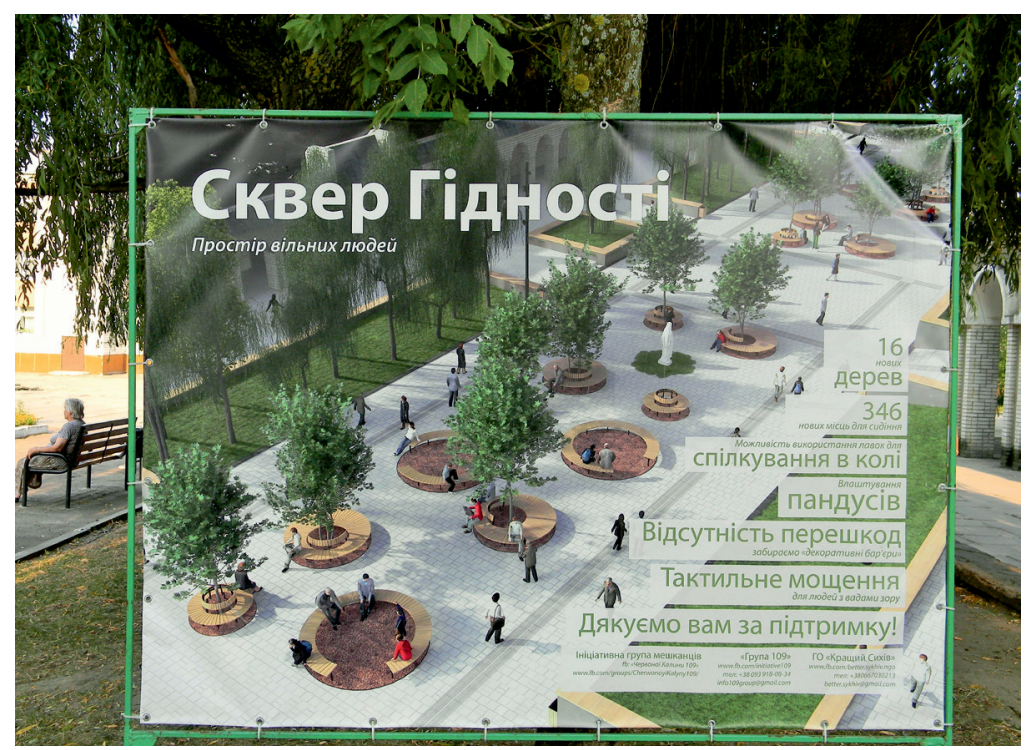

Figure 2. Project of reconstruction of "the Square of Dignity. Space of Free People" Text in Ukrainian: 16 new trees, 346 new places for sitting, possibility to use benches for conversation in the circle, arrangement of ramps, no obstacles, remove "decorative barriers", tactile paving for people with visual impairment, thank you for your support! Initiative group of inhabitants, 109 Group, NGO "Better Sykhiv"

\section{photo: N. Otrishchenko (2015)}

The majority of persons in a quantitative survey (around $75 \%$ of respondents from Sykhiv) agree with local activists and declare that people have to care about the condition of common spaces such as a porch and the adjacent territory to buildings (see Table 2). At the same time, almost one fifth of the sample either agree or completely agree with the statement that people have to care mainly about personal comfort in the apartment. This tendency might be also illustrated with skeptical voices from interviews: "People do not want to take responsibility, they are hiding in the crowd" 21 or "whatever European practices are, you bring them to the table, and people still can say that there is some deception. There is no trust even between neighbors, [only] there is [trust] between the neighbors on the

\footnotetext{
${ }^{20}$ Female, 31, 21 July 2015.

${ }^{21}$ Ibidem.
} 
same floor"22. Urban spaces might be transformed much faster not by singe actor but by a group of people with the certain level of trust; the mere desire for changes usually is not enough.

Table 2. Attitudes of Sykhiv Inhabitants towards Common Spaces (\%)*

1) I should care only about my personal comfort in the apartment, and do not think about the condition of common spaces, such as porch, territory near building, public places

2) I should think not only about comfort in my apartment, but also care about the condition of common spaces, such as porch, territory near building, 73,0 public places

3) The condition of common spaces, such as porch, territory near building, public space depends on the activities of the residents

$* \%$ of those who either agree or completely agree with the statement.

Source: Lviv city institute survey (2017).

Sykhiv has multiple traditions in terms of existing social networks. First of all, the housing estate was developed mainly for the workers of industrial hub who migrated on a daily basis from the nearby villages. Those people settled together and preserved certain types of connections: "Literally neighbors in the villages settled together in [those] buildings... and certain traditions moved with the village and with these people into these houses" ${ }^{23}$. There also were strong social bonds between people who were forced to move from Prypiat in 1986: "In fact, this is our house, and it was divided into a 'Chornobyl' [people who were relocated after the accident at ChNPP] part and 'not a Chornobyl' [people from villages nearby] part... Those who come from there [from Chornobyl], when they were young, they wanted to do something together, and they planted trees" ${ }^{\prime 24}$. After 1989/1991, social composition changed. As a result, Sykhiv inhabitants now have diverse backgrounds and differ in terms of their economic capacities: "To someone there is no problem there to allocate one hundred hryvnias, someone has the problem of allocating ten hryvnias and, unfortunately, it is very difficult to do something together in such situations"25. This diversity could be one of the key resources of the area - a possibility to develop cross-cultural dialogue and overcome the tendencies of ghettoization.

\footnotetext{
${ }^{22}$ Male, 26, 14 July 2015.

${ }^{23}$ Ibidem.

${ }^{24}$ Male, 31, 7 August 2015.

${ }^{25}$ Male, 30, 6 August 2015.
} 


\section{Conclusions}

Active local community could become an avant-garde of spatial development. It resonated with ideas, expressed by Kenny Cupers: "The concept of community - with all its underlying sociological assumptions - was inserted into a new discourse, that of citizen participation. Community was now an expression of grassroots activism and protest" (Cupers 2016: 1024). Therefore, the difference between "socialist" and "post-socialist" places for common usage might be explained with other types of social bonds behind them, variation in their sustainability, and number of possibilities to use the place for your own.

Sykhiv inherited a number of community centers, libraries, places for practicing sports, green zones etc. Some of them could be used by local community and become centers of social life and interaction between neighbors. This residential area has a big density of populations and, therefore, a significant amount of human resources. Enhancement of existing social links and development of new ones under the favorable circumstances could contribute to the transformation of urban environment. The next challenge is to develop new transparent forms of interaction between spatial actors. After years of socialism and "wild capitalism" of 1990s it is necessary to set up a new system of rules, which would consider interests of all parties. Sykhiv already has an example of involving local residents into urban planning and spatial development of their neighborhood, but the process itself has to be clarified. What are the possibilities and limitations of such involvement? And are people ready to be involved, to invest their time, money, and other resources? Finally, existing places for community are good examples of "the life between the buildings", as they are constantly developed, negotiated, and supported by local inhabitants. These areas point to the connection between social and material tissues and visualize their interdependence.

\section{Bibliography}

Cherkes B., 2013, Socialistic Birth and Afterlife of the Largest Lviv District of Sykhiv, Dom i Osiedle Jutra, cz. 1, „Środowisko Mieszkaniowe”, 11: 68-73.

Crowley D., Reid S. (eds.), 2002, Socialist Spaces: Sites of Everyday Life in Eastern Bloc, Berg, Oxford.

Cupers K., 2016, Mapping and Making Community in the Postwar European City, „Journal of Urban History”, 42(6): 1009-1028.

Darieva T., Kaschuba W., Krebs M. (eds.), 2011, Urban Spaces after Socialism: Ethnographies of Public Places in Eurasian Cities, Campus, Frankfurt/Main.

Ihle A., 2002, Wandering the Streets of Socialism: A Discussion of the Street Photography of Arno Fischer and Ursula Arnold, [in:] Crowley D., Reid S. (eds.), Socialist Spaces: Sites of Everyday Life in Eastern Bloc, Berg, Oxford: 85-104.

Kleims A., Dmitrieva M. (eds.), 2010, The Post-Socialist City. Continuity and Change in Urban Space and Imagery, Jovis, Berlin. 
Meuser Ph., 2015, Ten Parameters for a Typology of Mass Housing, [in:] Meuser Ph., Zadorin D. (eds.), Towards a Typology of Soviet Mass Housing: Prefabrication in the USSR 1955-1991, DOM Publishers, Berlin: 10-159.

Project for Public Spaces, 2009, What Makes a Successful Place?, http://www.pps.org/ reference/grplacefeat/ (accessed on: 17.07.2017).

Sammartino A., 2016, Mass Housing, Late Modernism, and the Forging of Community in New York City and East Berlin, 1965-1989, „American Historical Review”, 121.2: 497. Szelenyi I., 1996, Cities under Socialism - and After, [in:] Andrusz G., Harloe M., Szelenyi I. (eds.), Cities After Socialism. Urban and Regional Change and Conflict in Post-Socialist Societies, Blackwell Publishers, Oxford: 286-317.

Zadorin D., 2009, Microrayon Handbook, The Block, 21: 26-35.

\section{(RE)DEFINIOWANIE MIEJSC WSPÓLNOTOWYCH NA OSIEDLU BLOKOWYM SYKHIV}

Zarys treści: Lwów (Ukraina) to miasto Europy Wschodniej z historią sięgającą XIII wieku. Można je sobie wyobrazić jako miejsce przypominające palimpsest o różnych walorach architektonicznych, społecznych i kulturowych. Jednak większość obecnej populacji Lwowa żyje w środowisku miejskim zaprojektowanym i zbudowanym w drugiej połowie $\mathrm{XX}$ wieku. Na podstawie danych socjologicznych (wywiady pogłębione częściowo ustrukturyzowane, ankieta i obserwacja ukryta) w artykule dokonano przeglądu specyfiki miejsc w przestrzeni miasta w największym osiedlu mieszkaniowym - Sykhiv. Autorka pokazuje, jakie obszary są postrzegane przez mieszkańców jako miejsca życia społecznego i jakie rodzaje spójności społecznej mogą przyczynić się do transformacji miejskich.

Słowa kluczowe: Społeczność, więzi społeczne, miasto postsocjalistyczne, wielkie osiedle mieszkaniowe, transformacja przestrzenna, Sykhiv, Lwów.

Natalia Otrishchenko, $\mathrm{PhD}$ Center for Urban History of East Central Europe, Lviv (Ukraine) e-mail: n.otrishchenko@lvivcenter.org.ua 